Formulasi Pembuatan Cokies dengan Metode Linier Programming - Pulungan, dkk Jurnal Pangan dan Agroindustri Vol.8 No.4: 208-218, Okt 2020

Diterima: 11/03/2020, Direview: 06/05/2020, Diterbitkan: 05/10/2020

\title{
FORMULASI PEMBUATAN COOKIES DENGAN METODE LINEAR PROGRAMMING
}

\section{Formulation of Making Cookies With Linear Programming Method}

\author{
Maimunah Hindun Pulungan*, Salsabila Ramadanti Gayu Putri, Claudia Gadizza Perdani \\ Jurusan Teknologi Industri Pertanian, FTP, Universitas Brawijaya \\ JI. Veteran, Malang 65145 \\ ${ }^{*}$ Penulis Korespondensi, Email: maimun2010@ub.ac.id
}

\begin{abstract}
ABSTRAK
Penelitian ini bertujuan mengetahui formulasi cookies berbahan tepung mocaf, tepung biji nangka dan biji labu kuning yang memiliki biaya minimal dan memenuhi standar SNI cookies menggunakan metode simplex linear programming, serta mengetahui sifat fisik, kimia, dan organoleptik produk cookies. Fungsi tujuan berupa minimasi biaya bahan baku. Fungsi kendala berupa batasan minimal dan kandungan kimia bahan baku sesuai SNI No. 01-2973-1992. Formulasi cookies terpilih memiliki komposisi tepung Mocaf $25 \mathrm{~g}$, tepung biji nangka $5 \mathrm{~g}$, biji labu kuning $5 \mathrm{~g}$, telur $20 \mathrm{~g}$, margarin $15 \mathrm{~g}$, gula halus $22 \mathrm{~g}$ dan susu skim $8 \mathrm{~g}$ dengan biaya minimal sebesar Rp 3.748,00. Karakteristik kimia cookies yaitu $75.38 \%$ karbohidrat, $5.36 \%$ protein, $15.65 \%$ lemak, $2.89 \%$ kadar air, $0.72 \%$ kadar abu, dan total kalori sebesar $463.81 \mathrm{kkal} / \mathrm{gram}$ serta daya patah $723.31 \mathrm{gram} / \mathrm{cm}$. Preferensi konsumen untuk kajian indikator warna, rasa, aroma, dan tekstur cookies adalah netral.
\end{abstract}

Kata kunci: Cookies; Linear programming

\section{ABSTRACT}

The study aims to determine cookies formulation made from Mocaf flour, jackfruit seed flour, and pumpkin seeds, which have minimal cost and based SNI standards using simple linear programming. Also, its objectives to determine the chemical, physical, and organoleptic cookies properties. The objective function is to minimize raw material costs. Constraint functions are the minimum limit and chemical content of raw material where the value standard based on SNI Number 01-2973-1992. The selected cookies formulation has $25 \mathrm{~g}$ Mocaf flour, $5 \mathrm{~g}$ jackfruit seed flour, $5 \mathrm{~g}$ pumpkin seeds, $20 \mathrm{~g}$ eggs, $15 \mathrm{~g}$ margarine, 22 $g$ refined sugar, $8 \mathrm{~g}$ skim milk with the minimum cost of Rp 3.748,00. Chemical characteristics: $75.38 \%$ carbohydrates, $5.36 \%$ protein, $15.65 \%$ fat, $2.89 \%$ water content, $0.72 \%$ ash content, and total calories of $463.81 \mathrm{kcal} / \mathrm{gram}$. Cookies have breaking strength $723.31 \mathrm{gram} / \mathrm{cm}$. Consumer preference for color, taste, aroma, and texture of cookies is neutral.

Keywords : Cookies; Linear programming

\section{PENDAHULUAN}

Cookies dapat dikatakan merupakan salah satu produk olahan pangan yang memiliki kepopuleran tinggi di Indonesia. Cookies siap dikonsumsi dimana saja tanpa memerlukan pengolahan terlebih dahulu. Cookies sangat disukai karena rasanya yang enak dan teksturnya yang renyah. Cookies mengandung kadar air yang rendah sehingga mempunyai kemampuan penyimpanan yang dikategorikan cukup lama atau panjang. Cookies mampu menjadi variasi olahan pangan yang secara klinis menggenapi asupan nutrisi khusus 
manusia, dikarenakan jenis makanan ini mengandung sejumlah nutrien penghasil energi terutama dari gugus lemak dan karbohidrat. Cookies diolah dari adonan, diantaranya tepung terigu, gula, lemak, dan tambahan bahan-bahan opsional seperti susu, garam, penyedap rasa, dan bahan lainnya dengan proses pemanggangan (Olapade and Adeyemo, 2014).

Bahan baku utama cookies secara umum merupakan tepung dari jenis terigu. Nilai permintaan bahan tepung terigu di Indonesia pada tahun 2016 mengalami peningkatan sebanyak 5.3\% dibandingkan tahun sebelumnya (APTINDO, 2016 dalam Rahmadian, 2018) menyebabkan impor gandum mengalami kenaikan. Inisiatif solusi yang ditawarkan untuk menekan ketergantungan impor bahan tepung terigu di Indonesia ialah dengan melakukan substitusi bahan tepung terigu dengan jenis-jenis tepung yang terbuat dari umbi-umbian, kacang-kacangan, dan biji-bijian. Salah satu umbi-umbian yaitu ubi kayu atau biasa dijuluki dengan singkong.

Ubi kayu atau sebutan lain singkong ini merupakan kategori pangan lokal asli yang potensial untuk menjadi bahan opsional tepung terigu. Singkong dapat diolah menjadi Mocaf atau disebut dengan Modified Cassava Flour, dimana melalui proses pengolahannya memanfaatkan teknik fermentasi. Tepung Mocaf memiliki kadar karbohidrat yang terkategori cukup tinggi dan daya gelasi yang berlevel lebih rendah jika dikomparasikan dengan tepung terigu. Komposisi serat pada jenis olahan tepung Mocaf sejumlah $12 \%$, yakni dikatakan lebih tinggi jika dikomparasikan dengan tepung terigu (Risti dan Rahayuni, 2013). Kandungan protein yang tidak terlalu besar pada tepung Mocaf menyebabkan perlu ditambah bahan lain untuk meningkatkan kandungan protein, salah satunya dari biji-bijian misalnya biji nangka dan biji labu. Biji nangka sebagai pangan lokal berpotensi untuk dikembangkan menjadi tepung biji nangka (Fajar, Riyadi, dan Anggo, 2016). Bahan lokal lain yang mengandung sumber protein yaitu biji labu kuning. Menurut Graves (2016), biji labu kuning selain tinggi akan antioksidan juga mengandung phytosterol yang dapat mengurangi kolesterol, triptofan, mineral termasuk zat besi, seng, tembaga, magnesium dan fosfor, dan lemak tak jenuh tunggal. Dari ketiga bahan tersebut diharapkan dapat dimanfaatkan dalam pembuatan cookies dan dapat memenuhi standar mutu cookies sesuai SNI No. 01-2973-1992.

Pembuatan formulasi makanan salah satunya dapat menggunakan metode linear programming. Metode ini didahului dengan analisa sederhana seperti kandungan bahan baku dan biaya bahan baku yang akan dimasukkan kedalam model matematis berupa fungsi tujuan (objective function) dan fungsi kendala (obstacle function). Fungsi tujuan (objective function) dapat berupa minimasi atau maksimasi dan fungsi kendala merupakan batasan-batasan yang digunakan seperti menentukan batasan maksimal atau minimal jumlah bahan baku dan menetukan kandungan kimia produk akhir yang akan dituju. Hariadi, Effendi, dan Achyadi (2017), mengaplikasikan linear programming pada formulasi peramuan jenis cookies dari tepung komposit yakni kacang kedelai, bonggol pisang batu, dan jagung), dengan tujuan optimasi bahan-bahan baku, dalam hal ini adalah tepung. Faktor kendala yaitu harga bahan baku dan faktor pembatas ialah pengomparasian bahan-bahan baku jenis tepung komposit dengan acuan nilai pembatas sesuai dengan SNI Nomor 012973-1992. Serupa dengan penelitian Sheibani et al., (2018) bahwa metode linear programming dapat digunakan dalam pembuatan formulasi pangan darurat. Berdasarkan uraian tersebut, maka penulis akan menggunakan metode linear programming dalam formulasi pembuatan cookies, dengan fungsi tujuan berupa minimasi biaya dan fungsi batasan berupa standar mutu cookies SNI No. 01-2973-1992.

\section{BAHAN DAN METODE}

\section{Bahan}

Bahan baku penelitian meliputi tepung Mocaf merk "Sinar Lintang", tepung biji nangka merk "lels Organic Food", biji labu kuning merk "Trio Natural", gula halus merk "Cap Semut", margarin merk "Blue Band", susu skim, dan telur. Bahan-bahan yang dimanfaatkan sebagai 
analisis adalah $\mathrm{NaOH} 45 \%$, aquades, $\mathrm{HCL} 0,1 \mathrm{~N}, \mathrm{H}_{2} \mathrm{SO}_{4}$ pekat, tablet kjedahl, $\mathrm{H}_{3} \mathrm{BO}_{3} 3 \%$ Petroleum Eter (PE), $\mathrm{K}_{2} \mathrm{SO}_{4} 10 \%$, nelson $\mathrm{A}$, nelson $\mathrm{B}$, alkohol $95 \%$ dan kertas saring.

Alat

Alat-alat yang dipergunakan pada pembuatan cookies adalah mixer "Mixer Oriflame Cosmos", baskom, timbangan analitik "AND GR-200", pengaduk, loyang, dan oven "Kirin 19l". Jenis peralatan-peralatan yang dimanfaatkan untuk kajian analisis ialah terdiri atas Erlenmeyer (Pyrex), tabung reaksi, oven (Memmert), cawan petri, soxhlet, rak tabung reaksi, pipet ukur, spatula, pipet tetes, gelas ukur, beaker glass (Pyrex), desikator, destilator, labu kjeldahl (Pyrex), timbangan analitik (Mettler), corong plastik, dan kertas saring.

\section{Desain Penelitian}

Model pengaturan penelitian yang dilakukan oleh peneliti terdiri atas tiga tahap, yakni tahap penelitian pertama, tahap penelitian kedua, dan tahap penelitian ketiga. Tahapan penelitian tahap pertama yaitu karakterisasi bahan baku, penelitian tahap kedua yaitu pemodelan formulasi matematis produk dengan metode linear programming dan penelitian tahap ketiga yaitu validasi kesesuain produk

\section{Tahapan Penelitian}

Tahapan proses pembuatan cookies diawali dengan menyiapkan peralatan yang digunakan dan bahan baku yang dibutuhkan sesuai dengan hasil formulasi. Tahap selanjutnya campurkan bahan tambahan yaitu telur, margarine, gula halus, dan susu skim memanfaatkan alat mixer melalui pengaturan kecepatan tingkat rendah dalam waktu 5 menit. Adonan krim yang sudah jadi dicampurkan dengan bahan utama yaitu tepung Mocaf, tepung biji nangka dan biji labu kuning menggunakan mixer kurang lebih selama 5 menit. adonan yang telah lunak dicetak dengan cekungan sendok makan. Selanjutnya, adonan tercetak kemudian dioven pada pengaturan suhu kurang lebih $140^{\circ} \mathrm{C}$ selama 30 menit dan cookies yang sudah matang kemudian didinginkan pada suhu ruang.

\section{Metode Penelitian}

Penentuan formulasi model matematis cookies dilakukan dengan metode simplex linear programming dengan bantuan perangkat lunak LiPS-1.11.1. Fungsi tujuan berupa minimasi biaya dan fungsi batasan berupa jumlah batas bahan baku dan kandungan kimia bahan baku sesuai syarat mutu cookies SNI 01-2973-1992. Pembuatan produk formulasi yang terpilih dilakukan uji validasi. Data yang dibutuhkan dalam validasi model formulasi cookies adalah data mengenai kandungan nutrisi cookies meliputi kadar karbohidrat, total kalori, kadar protein, dan kadar lemak yang kemudian dilihat kesesuaiannya terhadap batasan yang digunakan yaitu syarat baku mutu produk olahan cookies SNI Nomor 01-2973-1992. Analisa organoleptik menggunakan uji hedonik (kesukaan).

\section{Prosedur Analisis}

Pengujian produk meliputi uji kimia, uji fisika, dan uji organoleptik. Uji kimia yaitu kadar lemak metode soxhlet (AOAC, 2005), kadar protein metode kjedahl (AOAC, 2005), kadar abu (AOAC, 2005), kadar karbohidrat by different (AOAC, 2005), total kalori dengan perhitungan empiris (Institute of Medicine, 2002) dan kadar air metode oven (AOAC, 2005). Uji Fisik meliputi daya patah dengan tensile strength. Uji organoleptik didasarkan pada metode uji penerimaan berupa uji hedonik dengan parameter yakni rasa, warna, aroma, dan tekstur (Setyaningsih, Apriyantono, dan Sari, 2010). Uji organoleptik dilakukan pada hasil formulasi dari linear programming dengan biaya terendah menggunakan subjek sejumlah panelis yang dikategorikan tidak terlatih sebanyak 30 orang.

\section{HASIL DAN PEMBAHASAN}

\section{Karakteristik Kimia Bahan Baku}


Hasil analisis kandungan kimia tepung Mocaf, tepung biji labu kuning, dan tepung biji nangka terdapat pada Tabel 1.

Tabel 1. Perbandingan Kandungan Kimia Bahan Baku Utama Cookies

\begin{tabular}{llllllll}
\hline \multirow{2}{*}{ No } & \multirow{2}{*}{ Parameter } & \multicolumn{2}{c}{ Tepung Mocaf } & \multicolumn{2}{c}{ Tepung Biji Nangka } & \multicolumn{2}{c}{ Biji Labu Kuning } \\
\cline { 3 - 7 } & & Analisis & Pustaka* $^{*}$ & Analisis & Pustaka* & Analisis & Pustaka $^{\star \star \star}$ \\
\hline 1 & Karbohidrat (\%) & 81.51 & 85.60 & 76.21 & 79.34 & 75.31 & 33.11 \\
2 & Protein (\%) & 2.41 & 1.93 & 9.75 & 13.50 & 8.69 & 31.98 \\
3 & Lemak (\%) & 1.87 & 2.72 & 1.34 & 1.27 & 4.97 & 38.29 \\
4 & Kadar Air (\%) & 11.32 & 9.25 & 9.58 & 6.09 & 8.32 & 4.43 \\
5 & Abu (\%) & 2.79 & 0.30 & 3.12 & 2.75 & 2.71 & 2.36 \\
6 & Kalori (Kkal) & 35.91 & 374.60 & 355.90 & 382.36 & 380.73 & - \\
\hline
\end{tabular}

Sumber: *(Subagio et al., 2008), ${ }^{* *}$ (Pangesti, Natsir, dan Sudjarwo, 2016), ${ }^{* * *}$ (Devi, Prasad, dan Palmei, 2018)

Hasil analisis kandungan kimia tepung Mocaf pada Tabel 1. diperoleh kadar karbohidrat, kadar lemak, dan total kalori tepung Mocaf hasil analisis lebih rendah dibandingkan dengan literatur. Nilai kadar air, kadar protein, dan nilai kadar abu hasil analisis tepung Mocaf cukup tinggi dibandingkan dengan literatur. Perbedaan kandungan kimia yang diperoleh diduga dipengaruhi oleh lama proses fermentasi dan jenis starter yang digunakan. Menurut Iswari, Hastuti, dan Srimaryati (2016) menyatakan hasil penelitian jika semakin lama indikator waktu fermentasi, maka nilai kadar karbohidrat pada tepung Mocaf akan semakin rendah dan selama proses fermentasi pada pembuatan tepung Mocaf, kadar protein dapat meningkat seiring dengan meningkatnya massa sel. Semakin lama fermentasi maka kadar abu akan semakin meningkat (Iswari, Hastuti, dan Srimaryati 2016). Selain itu, kadar asam lemak bebas bahan dapat dipengaruhi proses fermentasi yang dilakukan pada bahan baku, kadar lemak total semakin tinggi seiring dengan meningkatnya level starter BAL (Amanu dan Susanto, 2014). Perbedaan kadar air hasil analisis dan literatur dipengaruhi oleh lama pengeringan pembuatan tepung Mocaf (Loebis et al., 2013).

Hasil analisis kandungan kimia tepung biji nangka pada Tabel 1. diperoleh kadar karbohidrat, kadar protein, dan total kalori tepung biji nangka hasil analisis cukup rendah dibandingkan dengan literatur. Kadar abu, kadar lemak, dan kadar air tepung biji nangka hasil analisis cukup tinggi dibandingkan dengan literatur. Perbedaan yang terjadi diduga dipengaruhi oleh suhu pengeringan pada pembuatan tepung biji nangka. Menurut Kusumawati, Amanto, dan Muhammad (2012), kadar karbohidrat biji nangka yang diolah menjadi tepung akan mengalami peningkatan seiring dengan tingginya suhu pengeringan, karena adanya hidrolisis pati dari kegiatan enzim amylase. Selain itu, jika semakin tinggi pengaturan temperatur yang dibuat, maka semakin rendah nilai kadar airnya dan kadar abu pada bahan yang mengalami penguraian lebih banyak dibandingkan dengan pengeringan menggunakan suhu rendah (Kusumawati, Amanto, dan Muhammad, 2012). Perbedaan kadar lemak dapat disebabkan oleh suhu, dimana semakin tinggi pengaturan temperatur, maka nilai level kerusakan lemak dinyatakan akan semakin kuat (Andryarini dan Hidayati, 2017). Menurut Yulianti, Ratman, dan Solfarina (2015), proses pemanasan dapat menyebabkan protein mengalami denaturasi yang mengakibatkan protein menjadi rusak

Hasil analisis kandungan kimia tepung biji labu kuning pada Tabel 1. diperoleh bahwa kadar protein, kadar lemak, dan kadar karbohidrat biji labu kuning hasil analisis memiliki nilai yang lebih rendah jika dikomparasikan dengan literatur. Sementara, nilai kadar air dan nilai kadar abu tepung biji nangka hasil analisis lebih tinggi dibandingkan dengan literatur. Perbedaan kandungan yang terjadi diduga dipengaruhi oleh pemanenan buah labu kuning dan pengolahan biji labu kuning yang dilakukan. Sesuai dengan Hertiningsih (2003) dalam Sarungallo et al. (2018), bahwa kadar air, protein, lemak dan karbohidrat biji sangat dipengaruhi oleh umur panen biji. Kematangan buah mempengaruhi kadar air biji buah, kadar air menurun seiring dengan semakin masaknya buah (Darmawan, Respatijarti, dan Soetopo, 2014). Proses pemanasan juga dapat mengurangi kandungan protein dalam biji labu akibat denaturasi protein (Widya, Anjani, dan Syauqy, 2019). 


\section{Formulasi}

Formula cookies ini menggunakan metode linear programming dengan aplikasi LiPS1.11.1 untuk menentukan model matematis dari fungsi tujuan dan fungsi kendala. Komposisi cookies terdiri dari tujuh bahan baku yaitu tepung Mocaf $\left(X_{1}\right)$, tepung biji nangka $\left(X_{2}\right)$, biji labu kuning $\left(X_{3}\right)$, telur $\left(X_{4}\right)$, margarin $\left(X_{5}\right)$, gula halus $\left(X_{6}\right)$ dan susu skim $\left(X_{7}\right)$. Berikut adalah model matematis cookies:

\section{a. Fungsi Tujuan}

Fungsi tujuan dari model berupa minimasi biaya untuk mendapatkan harga paling minimal berdasarkan penggunaan bahan baku dengan memperhatikan beberapa fungsi kendala yang harus dipenuhi

Tabel 2. Harga Tiap Bahan Baku

\begin{tabular}{lc}
\hline \multicolumn{1}{c}{ Bahan } & Harga per 1 gram (Rp) \\
\hline Tepung Mocaf $\left(X_{1}\right)$ & 25 \\
Tepung Biji Nangka $\left(X_{2}\right)$ & 168 \\
Biji Labu Kuning $\left(X_{3}\right)$ & 118 \\
Telur $\left(X_{4}\right)$ & 19 \\
Margarin $\left(X_{5}\right)$ & 25 \\
Gula Halus $\left(X_{6}\right)$ & 19 \\
Susu Skim $\left(X_{7}\right)$ & 65 \\
\hline
\end{tabular}

Harga bahan baku yang digunakan pada berdasarkan Tabel 2 yaitu harga bahan baku per 1 gram. Harga bahan baku akan dimasukkan kedalam model matematis fungsi tujuan yang akan dijadikan sebagai input ke dalam aplikasi LiPS-1.11.1. Berikut merupakan model matematis fungsi tujuan cookies:

$Z_{\min }=25 X_{1}+168 X_{2}+118 X_{3}+19 X_{4}+25 X_{5}+19 X_{6}+65 X_{7}$

\section{b. Fungsi Kendala}

Tabel 3. Kandungan Kimia Bahan Baku Cookies

\begin{tabular}{lcccc}
\hline \multicolumn{1}{c}{ Bahan Baku } & Karbohidrat & Protein & Lemak & Total Kalori \\
\hline Tepung Mocaf $^{\mathrm{a}}$ & 81.61 & 2.41 & 1.87 & 352.91 \\
Tepung Biji Nangka $^{\mathrm{a}}$ & 76.21 & 9.75 & 1.34 & 355.90 \\
Biji Labu Kuning $^{\mathrm{a}}$ & 75.31 & 8.69 & 4.97 & 380.73 \\
Telur $^{\mathrm{b}}$ & 16.3 & 31.9 & 0.7 & 361 \\
Margarin $^{\mathrm{c}}$ & - & - & 66.67 & 600.03 \\
Gula Halus $^{\mathrm{d}}$ & 9.99 & - & - & 395.96 \\
Susu Skim $^{\mathrm{e}}$ & 52 & 10 & 25.6 & 362 \\
\hline
\end{tabular}

Ket: ${ }^{a}=$ Hasil Analisis Penelitian, ${ }^{b}=$ Direktorat Gizi Departemen Kesehatan R.I (1967), c $=$ Label Kemasan "Blue Band", ${ }^{d}=$ Thorpe dan Whiteley (1937), ${ }^{e}=$ Hariadi, Effendi, dan Achyadi (2017)

Berdasarkan kandungan kimia bahan baku pada Tabel 3 meliputi kadar karbohidrat, kadar protein, kadar lemak dan total kalori bahan baku akan dimasukkan sebagai input kedalam model matematis fungsi kendala. Model matematis fungsi kendala cookies adalah sebagai berikut:

- Total kalori:

$3,5291 X_{1}+3.559 X_{2}+3.8073 X_{3}+3.61 X_{4}+6.0003 X_{5}+3.9596 X_{6}+3.62 X_{7} \geq 400$

- Kadar protein:

$0.0241 X_{1}+0.0975 X_{2}+0.0869 X_{3}+0.163 X_{4}+0.01 X_{7} \geq 0.06$

- Kadar lemak 
$0.0187 X_{1}+0.0134 X_{2}+0.0497 X_{3}+0.319 X_{4}+0.6667 X_{5}+0.356 X_{7} \geq 0.1$

- Kadar karbohidrat

$$
0.8161 X_{1}+0.7621 X_{2}+0.7531 X_{3}+0.007 X_{4}+0.9899 X_{6}+0.356 X_{7} \geq 0.7
$$

- Total Berat Cookies 100 gram

$$
X_{1}+X_{2}+X_{3}+X_{4}+X_{5}+X_{6}+X_{7}=100
$$

- Total berat campuran tepung Mocaf, tepung biji nangka dan biji labu 35 gram

$$
X_{1}+X_{2}+X_{3}=35 \text { gram }
$$

- Jumlah tepung Mocaf, tepung biji nangka, biji labu kuning minimal 5 gram

$$
\mathrm{X}_{1}, \mathrm{X}_{2}, \mathrm{X}_{3}>=5 \text {. }
$$

- Jumlah telur dibatasi antara 14-20 gram

$$
20=\mathrm{X}_{4}>=14
$$

- Jumlah margarin maksimal $15 \mathrm{gram}$ $\mathrm{X}_{5}>=15$.

- Jumlah gula halus maksimal 10 gram $\mathrm{X}_{6}>=10$.

- Jumlah susu skim dibatasi maksimal 8 gram. $\mathrm{X}_{7}>=8$

Model matematis dari fungsi kendala ini meliputi batasan yang digunakan untuk menghasilkan produk akhir cookies yang sesuai dengan syarat mutu cookies SNI yaitu total kalori minimal $400 \mathrm{kkal}$, protein minimal 6\%, lemak minimal 10\% dan karbohidrat minimal $70 \%$.

Tabel 4. Formulasi Cookies Hasil Perhitungan program linear

\begin{tabular}{ccc}
\hline No & Bahan Baku & Jumlah $\mathbf{( g )}$ \\
\hline 1 & Tepung Mocaf & 25 \\
2 & Tepung Biji Nangka & 5 \\
3 & Biji Labu Kuning & 5 \\
4 & Telur & 20 \\
5 & Margarin & 15 \\
6 & Gula Halus & 22 \\
7 & Susu Skim & 8 \\
\hline & Harga (Rp) & $3.748,00$ \\
\hline
\end{tabular}

Berdasarkan Tabel 4. setelah dilakukan perhitungan menggunakan metode linear programming dengan bantuan aplikasi berupa LiPS-1.11.1, diperoleh formulasi terbaik cookies yaitu dengan biaya minimum sebesar Rp 3.748,00 per 100 gram dengan komposisi bahan baku yaitu tepung Mocaf sebesar 25 gram, tepung biji nangka sebesar 5 gram, biji labu kuning sebesar 5 gram, telur sebesar 20 gram, margarin sebesar 15 gram, gula halus sebesar 22 gram, dan susu skim sebesar 8 gram.

\section{Hasil Uji Validasi}

Validasi dilakukan dengan melakukan uji proksimat terhadap cookies untuk mengetahui kandungan kimia cookies tersebut dan membandingkannya dengan model formulasi. Hasil uji proksimat cookies hasil formulasi dijabarkan melalui Tabel 5.

Tabel 5. Hasil Uji Proksimat Cookies

\begin{tabular}{lccc}
\hline \multicolumn{1}{c}{ Parameter } & Nilai & SNI & Kesesuaian Model \\
\hline Karbohidrat (\%) & 75.38 & Min 70 & $100 \%$ \\
Protein (\%) & 5.36 & Min 6 & $89.3 \%$ \\
Lemak (\%) & 15.65 & Min 10 & $100 \%$ \\
Air (\%) & 2.89 & Maks 5 & $100 \%$ \\
Abu (\%) & 0.72 & Maks 2 & $100 \%$ \\
Total Kalori (kkal) & 463.81 & Min 400 & $100 \%$ \\
\hline
\end{tabular}


Tabel 5. menunjukkan bahwa setiap parameter kimia cookies sudah memenuhi kesesuaian model, kecuali pada parameter protein cookies hasil formulasi belum memenuhi syarat mutu cookies SNI, dimana diperoleh nilai protein sebesar 5.36 lebih kecil dari batas yang ditentukan yaitu minimum 6 . Hal ini diduga karena rendahnya kandungan protein tepung Mocaf yaitu sebesar $2.41 \%$ per 100 gram, dengan jumlah penambahan proporsi pada adonan cookies paling dominan yaitu sebesar $25 \%$ per 100 gram. Hal tersebut sesuai dengan pernyataan Oktaviana, Hersoelistyorini, dan Nurhidajah (2017), semakin tinggi level nilai penggunaan jenis bahan tepung mocaf pada cookies, dapat dikatakan pula akan semakin rendah nilai kadar protein cookies. Rendahnya kadar protein juga dapat disebabkan kerusakan protein akibat penggunaan suhu yang tinggi pada pengolahan produk. Menurut Sundari, Almasyhuri, dan Lamid (2015), semakin tinggi pengaturan temperatur dan periode yang lama pada waktu pemanggangan, dapat dinyatakan bahwa akibatnya semakin tinggi level perombakan destruktif protein yang dialami pada jenis produk olahan pangan tersebut. Pengolahan produk pangan yang menggunakan suhu tinggi juga dapat menurunkan kadar protein yang terkandung karena protein akan mengalami reaksi kimia berupa karamelisasi, yakni proses pencoklatan non-enzimatis atau biasa disebut reaksi maillard. Reaksi maillard ialah serangkaian tahapan pencoklatan (browning) yang muncul pada suatu produk pangan, dimana umumnya disebabkan oleh jenis reaksi kimia antara gula-gula reduksi, yang mana reaksi maillard pada suhu tinggi akan meningkat tajam dan menyebabkan pencoklatan semakin cepat terjadi (Winarno, 1997).

\section{Hasil Organoleptik Uji Hedonik Cookies}

Uji hedonik diterapkan dalam rangka untuk memperoleh data tingkat preferensi panelis-panelis terhadap jenis produk cookies yang meliputi parameter berupa rasa, tekstur, aroma, dan warna. Uji hedonik ini menggunakan panelis 30 orang tidak terlatih dengan scale scoring 5 skala. Hasil pengujian hedonik dinyatakan secara rinci pada Tabel 6.

Tabel 6. Hasil Uji Organoleptik (Hedonik) Cookies Hasil Formulasi dan Komersial

\begin{tabular}{cccc}
\hline Parameter & Produk & Rata-rata & Notasi \\
\hline \multirow{2}{*}{ Warna } & Cookies Formulasi & 3.50 & $\mathrm{~A}$ \\
& Cookies Komersial & 3.93 & $\mathrm{~A}$ \\
\multirow{2}{*}{ Rasa } & Cookies Formulasi & 3.73 & $\mathrm{~A}$ \\
& Cookies Komersial & 3.67 & $\mathrm{~A}$ \\
\multirow{2}{*}{ Aroma } & Cookies Formulasi & 3.77 & $\mathrm{~A}$ \\
& Cookies Komersial & 3.40 & $\mathrm{~A}$ \\
\multirow{2}{*}{ Tekstur } & Cookies Formulasi & 3.50 & $\mathrm{~A}$ \\
& Cookies Komersial & 3.87 & $\mathrm{~A}$ \\
\hline
\end{tabular}

\section{a. Warna}

Berdasarkan analisa organoleptik pada Tabel 6. dapat diketahui tingkat kesukaan panelis terhadap parameter warna cookies formulasi dan cookies komersial tidak ditemukan nilai perbedaan yang terbilang nyata. Rerata nilai preferensi warna kedua produk cookies berada di rentang 3 yang berarti tingkat kesukaan panelis terhadap warna cookies hasil formulasi dan cookies komersial adalah netral. Menurut Raharja (2018), menjelaskan bahwa warna butter cookies yang menggunakan tepung Mocaf sebagai bahan utama adalah kuning kecoklatan, yang tidak berbeda dengan butter cookies secara umum. Selain itu, warna cookies yang sedikit kecoklatan yang terjadi karena adanya reaksi maillard. Reaksi pencokelatan non enzimatik, yaitu karamelisasi dan reaksi maillard terjadi karena proses pemanggangan yang dapat mempengaruhi warna cookies, makin lama pemanggangan maka warna produk yang dihasilkan akan semakin cokelat (Winarno, 2002). Penggunaan gula pada pembuatan suatu produk juga dapat menimbulkan reaksi pencoklatan akibat reaksi maillard. Reaksi maillard atau reaksi pencoklatan merupakan reaksi antara karbohidrat, khususnya gula pereduksi dengan gugus amina primer, yang proses reaksinya 
diakhiri dengan pembentukan polimer bitroden bewarna coklat atau melanoid (Deman, 1997).

\section{b. Rasa}

Berdasarkan analisa organoleptik pada Tabel 6. dapat diketahui tingkat kesukaan panelis terhadap parameter rasa cookies formulasi dan cookies komersial tidak terdapat perbedaan yang nyata. Rata-rata nilai kesukaan rasa kedua produk cookies berada di rentang 3 yang berarti tingkat kesukaan panelis terhadap produk cookies hasil formulasi dan cookies komersial adalah netral. Rasa dari cookies dipengaruhi dari bahan yang digunakan dalam pembuatan cookies tersebut. Rasa asam yang terdapat pada tepung Mocaf tidak terasa pada cookies yang dihasilkan karena rasa yang terbentuk dapat dibantu dengan bahan pendukung lainnya seperti telur, susu skim, margarin dan gula halus (Oktaviana, Hersoelistyorini, dan Nurhidajah, 2017). Menurut Gracia, Sugiyono, dan Haryanto (2009), penambahan bahan seperti gula, margarin dan telur mempengaruhi rasa cookies yang dihasilkan, semakin tinggi jumlah penambahan bahan tersebut diberikan maka cookies akan semakin disukai panelis.

\section{c. Aroma}

Berdasarkan analisa organoleptik pada Tabel 6. dapat diketahui tingkat kesukaan panelis terhadap parameter aroma cookies formulasi dan cookies komersial tidak terdapat perbedaan yang nyata. Rata-rata nilai kesukaan aroma kedua produk cookies berada di rentang 3 yang berarti tingkat kesukaan panelis terhadap produk cookies hasil formulasi dan cookies komersial adalah netral. Rasa dari cookies dipengaruhi dari bahan yang digunakan dalam pembuatan cookies. Menurut penelitian Oktaviana, Hersoelistyorini, dan Nurhidajah (2017), semakin tinggi jumlah substitusi Mocaf semakin tinggi tingkat kesukaan panelis. Hal ini karena terjadi reaksi maillard selama pemanggangan sehingga menghasilkan aroma khas. Aroma tersebut semakin kuat apabila kadar protein bahan semakin tinggi. Aroma cookies juga dapat dipengaruhi oleh penambahan bahan lain seperti margarin, gula dan bahan pengembang (Subandoro, Basito, dan Atmaka, 2013).

\section{d. Tekstur}

Berdasarkan analisa organoleptik pada Tabel 6. dapat diketahui tingkat kesukaan panelis terhadap parameter tekstur cookies formulasi dan cookies komersial tidak terdapat perbedaan yang nyata. Rata-rata nilai kesukaan tekstur kedua produk cookies berada di rentang 3 yang berarti tingkat kesukaan panelis terhadap produk cookies hasil formulasi dan cookies komersial adalah netral. Tekstur pada cookies dipengaruhi oleh tiga komponen utama yaitu tepung, gula dan telur. Menurut Oktaviana, Hersoelistyorini, dan Nurhidajah (2017), penggunaan tepung Mocaf yang cukup tinggi akan menghasilkan cookies dengan tekstur yang kurang renyah. Hal ini dipengaruhi oleh kandungan amilosa dalam bahan, semakin rendah kadar amilosa dalam bahan maka kemampuan untuk mengikat airnya makin rendah, sehingga tekstur cookies yang dihasilkan menjadi keras (Nurani dan Yuwono, 2014). Penambahan margarine juga dapat mempengarhi tekstur cookies yang dihasilkan. Menurut Sarofa, Mulyani, dan Wibowo (2013), penambahan margarine yang semakin rendah maka cookies akan semakin keras, dikarenakan jumlah lemak yang terabsorpsi sedikit dan akan menghalangi struktur serat yang kuat. Selain itu, kandungan protein berupa gluten pada bahan dapat mempengaruhi tekstur cookies. Gluten berfungsi mengikat dan membuat struktur adonan menjadi kenyal, sehingga pada saat proses pemanggangan adonan akan mengembang dengan baik dan menghasilkan cookies yang renyah (Norhidayah, Noorlaila, dan Izzati, 2014). Menurut penelitian Kisnawaty dan Kurnia (2017), semakin tinggi substitusi tepung biji nangka pada pembuatan cookies, maka semakin rendah kandungan gluten pada adonan cookies.

\section{Hasil Uji Fisik (Daya Patah)}

Nilai daya patah cookies adalah $723.31 \mathrm{gram} / \mathrm{cm}$. Daya patah suatu produk pangan dapat dipengaruhi oleh bahan-bahan yang digunakan pada pengolahan produk tersebut. 
Menurut penelitian yang dilakukan Hazizah dan Estiasih (2013), daya patah pada cookies dapat dipengaruhi oleh penambahan jumlah margarin yang dilakukan karena margarin memberikan sifat plastis dalam merenyahkan cookies, dimana semakin meningkatnya penambahan margarin maka daya patah pada cookies akan menurun. Kandungan pati yang terdapat pada bahan mempengaruhi tekstur dan daya patah cookies melalui proses gelatinisasi yang terjadi saat proses pemanggangan. Meningkatnya proses gelatinisasi menyebabkan kandungan air dalam cookies semakin menurun dan cookies menjadi lebih mudah patah (Winarno, 2004). Selain itu, air yang terserap oleh pati saat proses pemanggangan dapat meninggalkan ruang kosong dalam adonan sehinnga menghasilkan tekstur cookies yang renyah dan mudah patah (Seyhun, Sumnu, dan Sahin, 2003).

\section{SIMPULAN}

Formulasi cookies yang terpilih menggunakan teknik linear programming berupa tepung Mocaf 25 gram, tepung biji nangka 5 gram, biji labu kuning 5 gram, telur 20 gram, margarin 15 gram, gula halus 22 gram, dan susu skim 8 gram, dengan biaya bahan baku paling minimum sebesar Rp 3.748,00 per 100 gram, memiliki daya patah sebesar 723.31 $\mathrm{gram} / \mathrm{cm}$. Hasil organoleptik uji hedonik tingkat kesukaan konsumen terhadap cookies komersial dan cookies hasil formulasi tidak berbeda nyata pada parameter warna, rasa, aroma, dan tekstur. Cookies hasil formulasi setiap 100 gram mengandung $75.38 \%$ karbohidrat, $5.6 \%$ protein, $15.65 \%$ lemak, $2.89 \%$ kadar air, $0.72 \%$ kadar abu dan total kalori sebesar $463.81 \mathrm{kkal} / \mathrm{gram}$. Setiap $100 \mathrm{gram}$ cookies sudah memenuhi standar cookies SNI 01-2973-1992 pada parameter karbohidrat, lemak, kadar air, kadar abu dan total kalori dengan kesesusaian model sebesar $100 \%$, sedangkan pada parameter protein kesesuaian model sebesar $89.3 \%$ dalam artian belum memenuhi standar SNI.

\section{DAFTAR PUSTAKA}

Amanu, F. N., \& Susanto, W. H. (2014). Pembuatan Tepung Mocaf Di Madura (Kajian Varietas Dan Lokasi Penanaman) Terhadap Mutu Dan Rendemen. Jurnal Pangan Dan Agroindustri, 2(3), 161-169.

Andryarini, E. N., \& Hidayati, I. (2017). Analisis Proksimat Pada Tepung Biji Nangka (Artocarpus Heterophyllus Lamk.). KLOROFIL, 1(1), 32-37.

AOAC. (2005). Official Methods of Analysis (18th Editi; W. liam Horwitz, Ed.). Maryland: AOAC International.

C.L, C. G., Sugiyono, \& Haryanto, B. (2009). Kajian Formulasi Biskuit Jagung Dalam Rangka Substitusi Tepung Terigu. Jurnal Teknologi Dan Industri Pangan, 20(1), 3240.

Darmawan, A. C., Respatijarti, \& Soetopo, L. (2014). Pengaruh Tingkat Kemasakan Benih Terhadap Pertumbuhan Dan Produksi Cabai Rawit (Capsicum frutescent L.) Varietas Comexio. Jurnal Produksi Tanaman, 2(4), 339-346.

Deman, J. M. (1997). Kimia Makanan (Edisi Kedu). Bandung: Penerbit ITB.

Devi, N. M., Prasad, R., \& Palmei, G. (2018). Physico-Chemical Characterisation Of Pumpkin Seeds. International Journal of Chemical Studies, 6(5), 828-831.

Direktorat Gizi Departemen Kesehatan R.I. (1967). Daftar Komposisi Bahan Makanan. Jakarta: Bhratara.

Fajar, R., Riyadi, P. H., \& Anggo, A. D. (2016). Pengaruh Kombinasi Tepung Biji Nangka (Artocarpus Heterophyllus Lamk.) Dan Tepung Tapioka Terhadap Sifat Fisik Dan Kimia Pasta Ikan Kurisi (Nemipterus Sp.). J. Peng. \& Biotek. Hasil Pi., 5(4).

Graves, L. (2016). Age-Proof: Beauty Alternatives You Need to Know. Sudbury: Archieboy Holdings Publishing Co.

Hariadi, H., Effendi, S., \& Sutisna Achyadi, N. (2017). Aplikasi Program Linear Dalam Pembuatan Formulasi Cookies Dari Tepung Komposit (Jagung, Kacang Kedelai Dan 
Bonggol Pisang Batu). Jurnal IImiah Rekayasa Pertanian Dan Biosistem, 5(1), 375384. https://doi.org/10.29303/jrpb.v5i1.46

Hazizah, H., \& Estiasih, T. (2013). Karakteristik Cookies Umbi Inferior Uwi Putih (Kajian Proporsi Tepung Uwi: Pati Jagung Dan Penambahan Margarin). Jurnal Pangan Dan Agroindustri, 1(1), 138-147.

Institute of Medicine. (2002). High-Energy, Nutrient-Dense Emergency Relief Food Product. https://doi.org/10.17226/10347

Iswari, K., Hastuti, H. F., \& Srimaryati. (2016). Pengaruh Lama Fermentasi Terhadap Mutu Tepung Cassava Termodifikasi. Prosiding Seminar Nasional Membangun Pertanian Modern Dan Inovatif Berkelanjutan Dalam Rangka Mendukung MEA, 1250-1257. Bogor: BB Pengkajian dan Pengembangan Teknologi Pertanian.

Kisnawaty, S. W., \& Kurnia, P. (2017). Pengaruh Substitusi Tepung Biji Nangka Pada Pembuatan Cookies Ditinjau Dari Kekerasan Dan Daya Terima. Seminar Nasional Gizi 2017 Program Studi IImu Gizi UMS "Strategi Optimasi Tumbuh Kembang Anak," 91104. Universitas Muhammadiyah Surakarta.

Kusumawati, D. D., Amanto, B. S., \& Muhammad, D. R. A. (2012). Pengaruh Perlakuan Pendahuluan Dan Suhu Pengeringan Terhadap Sifat Fisik, Kimia, Dan Sensori Tepung Biji Nangka (Artocarpus heterophyllus). Jurnal Teknosains Pangan, 1(1), 4148.

Loebis, E. H., Pohan, H. G., Meutia, Y. R., Wirawan, I., \& Novitasari, N. (2013). Implementasi Kultur Campuran Bakteri Asam Laktat Untuk "Scale UP" Produksi Tepung Mocaf. Warta IHP, 30(2), 31-42.

Norhidayah, M., Noorlaila, A., \& Nur Fatin Izzati, A. (2014). Textural And Sensorial Properties Of Cookies Prepared By Partial Substitution Of Wheat Flour With Unripe Banana (Musa X Paradisiaca Var. Tanduk And Musa Acuminata Var. Emas) Flour. International Food Research Journal, 21(6), 2133-2139.

Nurani, S., \& Yuwono, S. S. (2014). Pemanfaatan Tepung Kimpul (Xanthosoma sagittifolium) sebagai Bahan Baku Cookies (Kajian Proporsi Tepung dan Penambahan Margarin). Jurnal Pangan Dan Agroindustri, 2(2), 50-58.

Oktaviana, A. S., Hersoelistyorini, W., \& Nurhidajah. (2017). Kadar Protein, Daya Kembang, dan Organoleptik Cookies dengan Substitusi Tepung Mocaf dan Tepung Pisang Kepok. Jurnal Pangan Dan Gizi, 7(2), 72-81.

Olapade, A. A., \& Adeyemo, M. A. (2014). Evaluation of cookies produced from blends of wheat, cassava and cowpea flours. International Journal of Food Studies, 3(2), 175185. https://doi.org/10.7455/ijfs.v3i2.213

Pangesti, U., Natsir, M., \& Sudjarwo, E. (2016). Pengaruh Penggunaan Tepung Biji Nangka (Artocarpus heterophyllus) Dalam Pakan Terhadap Bobot Giblet Ayam Pedaging. TERNAK TROPIKA Journal of Tropical Animal Production, 17(2), 58-65. https://doi.org/10.21776/ub.jtapro.2016.017.02.8

Raharja, K. T. (2018). Receptivity Of Butter Cookies Using Mocaf (Modified Cassava Flour) Substitution. Journal of Applied Hospitality And Tourism Science, 1(1), 14-18.

Rahmadian, S. (2018). Pengaruh Proporsi Tepung Mocaf (Modified Cassava Flour) Dan Tepung Kacang Hijau (Vignia radiata L) Terhadap Kadar Protein Dan Daya Cerna Protein Food Bar. Universitas Muhammadiyah Surakarta, Surakarta.

Risti, Y., \& Rahayuni, A. (2013). Pengaruh Penambahan Telur Terhadap Kadar Protein, Serat, Tingkat Kekenyalan dan Penerimaan Mie Basah Bebas Gluten Berbahan Baku Tepung Komposit (Tepung Komposit: Tepung Mocaf, Tapoika dan Maizena). Journal of Nutrition College, 2(4), 696-703. https://doi.org/10.14710/jnc.v2i4.3833

Sarofa, U., Mulyani, T., \& Wibowo, Y. A. (2013). Pembuatan Cookies Berserat Tinggi Dengan Memanfaatkan Tepung Ampas Mangrove (Sonneratiacaseolaris). Jurnal Teknologi Pangan, 7(2), 58-67.

Sarungallo, Z. L., Susanti, C. M. E., Sinaga, N. I., Irbayanti, D. N., \& Latumahina, R. M. M. (2018). Kandungan Gizi Buah Pandan Laut (Pandanus tectorius Park.) pada Tiga Tingkat Kematangan. Jurnal Aplikasi Teknologi Pangan, 7(1), 21-26. 
https://doi.org/10.17728/jatp.2577

Setyaningsih, D., Apriyantono, A., \& Sari, M. P. (2010). Analisis Sensori untuk Industri Pangan dan Agro. Bogor: IPB Press.

Seyhun, N., Sumnu, G., \& Sahin, S. (2003). Effects of Different Emulsifier Types, Fat Contents, and Gum Types on Retardation of Stalling of Microwave-Baked Cakes. Nahrung/Food, 47(4), 248-251. https://doi.org/10.1002/food.200390058

Sheibani, E., Dabbagh Moghaddam, A., Sharifan, A., \& Afshari, Z. (2018). Linear Programming: An Alternative Approach for Developing Formulations for Emergency Food Products. Journal of the Science of Food and Agriculture, 98(4), 1444-1452. https://doi.org/10.1002/jsfa.8612

Subagio, A., Windrati, W. S., Witono, Y., \& Fahmi, F. (2008). Prosedur Operasai Standar (POS): Produksi Mocaf Berbasis Klaster. Bogor: FTP UNEJ-SEAFAST CENTER IPB.

Subandoro, R. H., Basito, \& Atmaka, W. (2013). Pemanfaatan Tepung Millet Kuning dan Tepung Ubi Jalar Kuning Sebagai Subtitusi Tepung Terigu dalam Pembuatan Cookies Terhadap Karakteristik Organoleptik dan Fisikokimia. Jurnal Teknosains Pangan, 2(4), 68-74.

Sundari, D., Almasyhuri, \& Lamid, A. (2015). Pengaruh Proses Pemasakan Terhadap Komposisi Zat Gizi Bahan Pangan Sumber Protein. Media Litbangkes, 25(4), 235242.

Thorpe, J. F., \& Whiteley, M. A. (1937). Thorpe's Dictionary of Applied Chemistry (Fourth edi). London: Longmans, Green and Co., Ltd.

Widya, F. C., Anjani, G., \& Syauqy, A. (2019). Analisis Kadar Protein, Asam Amino, Dan Daya Terima Pemberian Makanan Tambahan (Pmt) Pemulihan Berbasis Labu Kuning (Cucurbita Moschata) Untuk Batita Gizi Kurang. Journal of Nutrition College, 8(4), 207-218. https://doi.org/10.14710/jnc.v8i4.25834

Winarno, F. G. (1997). Kimia Pangan dan Gizi. Jakarta: Gramedia Pustaka Utama.

Winarno, F. G. (2002). Kimia Pangan dan Gizi. Jakarta: Gramedia Pustaka Utama.

Winarno, F. G. (2004). Kimia Pangan dan Gizi (Cetakan ke). Jakarta: Gramedia Pustaka Utama.

Yulianti, S., Ratman, R., \& Solfarina, S. (2015). Pengaruh Waktu Perebusan Biji Nangka (Artocapus heterophyllus Lamk) Terhadap Kadar Karbohidrat, Protein, Dan Lemak. Jurnal Akademika Kimia, 210. https://doi.org/10.22487/j24775185.2015.v4.i4.7873 